\title{
REGIME CHANGE AND MALAYSIA - JAPAN RELATIONS: EXPLAINING SHIFTS AND CONTINUITY IN FOREIGN POLICY
}

\author{
Geetha Govindasamy and Muhammad Danial Azman*
}

\begin{abstract}
The article offers an initial exploration into the causal linkage between domestic political regime change and foreign policy recalibration in Malaysia. While not popular, the notion that foreign policy objectives are more often than not shaped by internal dynamics is rather true in the Malaysian case. The discussion examines Malaysia's relations with Japan during the Pakatan Harapan government which began in May 2018 but collapsed by February 2020. After being sworn in as the Prime Minister of Malaysia for the second time, Dr. Mahathir Mohamad pledged to re-energize the Look East Policy to facilitate economic growth and investments into the country. Though the move was far from surprising, the consequence of the development needs to be understood within the broader context of Malaysia's domestic ties with China. Malaysia's move to expand cooperation with Japan can be explained by a desire to reduce overreliance on Chinese investments. The basic premise is that Malaysia was not tilting towards Japan, rather the move to court Japan through the LEP 2.0 was a function of regime legitimation through which Pakatan Harapan diversified its foreign policy partners for the goal of expanding investment and collaboration opportunities.
\end{abstract}

Keywords: Look East Policy, Pakatan Harapan, Japan, China, diversification

\section{INTRODUCTION}

Changes are permanent features of foreign policy decision-making of any government. The article is specifically interested to examine continuity and changes in Malaysian foreign policy after a switch in government. The main questions relate to how, when and what factors influence the fluctuation in policies. Generally, foreign policy of a nation changes in accordance to one's national interests. Additionally, continuity as well as shifts in policies occur in accordance to domestic and international factors. The article is an initial exploration into the causal linkages between domestic political regime change and foreign policy restructuring. While not popular, in the Malaysian case, the notion that foreign policy objectives are more often than not shaped by 
internal dynamics is rather true. The discussion explores Malaysia's relations with Japan during the administration of the Pakatan Harapan /Alliance of Hope (PH) government which began in May 2018 but collapsed unexpectedly by February 2020 via a coup by Muhyiddin Yassin. Malaysian foreign policy is usually managed by the "heavy imprint" of the prime minister of the day. ${ }^{1}$ One such example was the establishment of the Look East (LEP) policy in the early 1980s by the fourth Prime Minister of Malaysia, Dr. Mahathir Mohamad. Though the LEP was sustained by subsequent prime ministers, its implementation became weak and neglected as China took precedence over Japan in foreign policy considerations due to the external environment faced by Malaysia. To this end, while there were more continuity than changes in Malaysian foreign policy during PH's administration, Dr. Mahathir Mohamad who became the prime minister for a second time, pursued the resurgence of the LEP more vigorously. Though the LEP has always been the cornerstone of Malaysia-Japan bilateral relations, the fact that there was a change in government, prompted the renewed ascendancy of the policy due to Dr. Mahathir's Mohamad's second term leadership which preferred a more diverse foreign policy partners.

\section{OVERVIEW OF MALAYSIA-JAPAN RELATIONS}

Despite being colonized by the Japanese between 1941 and 1945, Kuala Lumpur has a robust relationship with Tokyo. Since 1957 Japan and Malaysia have enjoyed a good relationship in various spheres such as trade, investment, education, technology and culture. Just to recap, the world was amazed by the success of Japan's rapid economic development, particularly in the 1980s. Malaysian policymakers too were taken up by abilities of Japanese companies to penetrate world markets and were convinced this had to do with Japanese ethics, work culture and value system or in short the country's overall management style.

Not surprisingly, in 1982, Prime Minister Mahathir Mohamad (1981-2003) announced the LEP during the Fifth Annual Joint Conference of MAJECA-JAMECA (Malaysia-Japan Economic Association and Japan-Malaysia Economic Association). Not surprisingly, LEP played an important role in shaping Malaysia-Japan relationship in the subsequent years. Khadijah observed that the introduction of the policy was a "major turning point" in changing the nature of bilateral relations from one that was peripheral to that of a special relationship. ${ }^{2}$

In the past six decades, the strength of bilateral relations can be gauged by the extent to which bilateral trade has expanded. Warming up to Japan was not merely to acquire technological know-how or draw investments but to inculcate an Asian identity that was relatable within the Malaysian mindset. Additionally, the Japanese experience showed the extent to which state intervention could bring about economic growth. The government's control and influence over business was more pervasive. Understood as Japan Inc., cooperation between public-private partnerships, especially between 1970s and 1990s in targeting investments was another attractive

\footnotetext{
*This research was funded by the Sumitomo Foundation Grant 2019-2020.

${ }^{1}$ Elina Noor, Foreign and Security Policy in The New Malaysia, Lowy Institute, 7 November 2019, retrieved from https://www.lowyinstitute.org/publications/foreign-and-security-policy-new-malaysia, accessed on 8 November 2020.

${ }^{2}$ Khadijah Md Khalid, "Malaysia-Japan relations: Explaining the root causes of the pro-Japan orientation of Malaysia in the post1981 period," unpublished PhD thesis, London School of Oriental and African Studies - SOAS, University of London, 1999.
} 
feature that was viewed as essential in the promotion of the national economic development. According to Amyx and Drysdale, "Japan Inc. was a metaphor for an economy propelled forward by a system in which interests of big business, the Liberal Democratic Party (LDP) and the bureaucracy were aligned." 3 Therefore, it was not surprising that later Malaysia established the concept of Malaysia Incorporated, similar to that of Japan Inc., which highlighted a system where government and businesses were cooperative without being confrontational in nature. Japan saw the LEP as an opportunity to diversify its investments to Malaysia as well as move away from over dependence on the US. ${ }^{4}$

Japanese companies like Toray, Hitachi, Sony and Panasonic began investing more in Malaysia after the introduction of the LEP in 1982. With investments pouring in from Japanese companies, over the years Japan then become a key economic partner for Malaysian economic development. Since LEP became one of the main policy drivers in Malaysia-Japan relations in the subsequent decades, the situation eventually made Japan a dominant player, especially in the Malaysian industrialization process. The LEP increased Japanese investors' confidence in Malaysia and this in turn saw a rapid expansion of Japanese trade and investments into Malaysia over the years. Between1986-1990 bilateral trade accounted for USD8.08 billion but it increased exponentially during 1991-1995 to USD18.79 billion. ${ }^{5}$ According to the Japan External Trade Organization (JETRO), for most of the 1990s, Japan was the largest trading partner for Malaysia. ${ }^{6}$ According to Dato' Azman Mahmud, Malaysia Investment Development Authority's (MIDA) Chief operating office, "since the 1980s, Japan has been among the country's top source of foreign direct investments." Relations became further elevated when Japan signed the Economic Partnership Agreement with Malaysia in $2005 .^{7}$ The EPA became a pathway for cooperation in newer high tech industries and at the same time an avenue for small and medium Malaysian companies to obtain access into the manufacturing supply chain of Japanese companies. ${ }^{8}$ Years later, during the rejuvenation of LEP, Japan was the largest supplier of foreign direct investments in Malaysia in 2019. ${ }^{9}$

These days, Malaysian exports to Japan include petroleum and liquefied natural gas, electronic equipment, wood and wood products. ${ }^{10}$ Imports from Japan to Malaysia include Electronics, vehicles, machineries, iron and steel products. ${ }^{11}$ An estimated 1500 Japanese companies are currently operating in Malaysia. ${ }^{12}$ After decades of focusing investments in the

\footnotetext{
${ }^{3}$ J. Amyx, J. and P. Drysdale, (Eds.), Background. Japanese governance: Beyond Japan Inc. London, Routledge Curzon, 2003, p.1.

${ }^{4}$ Lai Yew Meng, Looking East Again? Malaysia-Japan Relations in the 21St Century, Manu, Vol.26, 2017, p.8.

${ }^{5}$ Rahman, K.M., Molla, R.I. \& Murad, M.W., Japan-Malaysia Free Trade Agreement: Expectations and achievements, Electronic Journal of Contemporary Japanese Studies, 2008, p 30.

${ }^{6}$ Kazuyaki Katayama, China's Rise and Japan's Malaysia Policy, UM Press, 2013, p.58.

${ }^{7}$ Kazuyaki Katayama, China’s Rise and Japan's Malaysia Policy, p.58.

${ }^{8}$ Malaysia External Trade Development Corporation, Bilateral Free Trade Agreements, retrieved on https://www.matrade.gov.my/en/etrade/24-malaysian-exporters/going-global/68-bilateral-fta, accessed on 12 August 2020.

${ }^{9}$ Japanese firms diversifying their investments in Malaysia, Bernama, 4 October 2020, https://www.freemalaysiatoday.com/category/nation/2020/10/04/japanese-firms-diversifying-their-investments-inmalaysia/

${ }^{10}$ Embassy of Japan in Malaysia, Overview of Japan-Malaysia Relationship, https://www.my.embjapan.go.jp/English/bilateral/Overview_bilateral.htm

${ }^{11}$ Embassy of Japan in Malaysia, Overview of Japan-Malaysia Relationship.

12 Japanese firms diversifying their investments in Malaysia.
} 
electrical and electronics sectors, Japanese companies in Malaysia are now moving into the health, medical device manufacturing, digital technology and halal food industries. ${ }^{13}$ This diversification is a function of the expected future changes that will occur in Malaysia with the introduction of the Industrial Revolution 4.0. (IR 4.0). Malaysian policymakers acknowledge that the country needs to learn from the extent to which Japan has encouraged collaboration between government, research and academia into its manufacturing industry in order to create solutions and innovations. ${ }^{14}$ Though the LEP remained relevant and Malaysia-Japan relations showed continued resilience, the rise of China began to impact on how the Malaysian leadership viewed Japan, especially under the administration of Prime Minister Najib Tun Razak (2009-2018). As Tang Siew Mun highlighted, though the Malaysia-Japan relationship was stable, yet relations plateaued as increasingly Malaysia pursued deeper ties with China. ${ }^{15}$ Consequently, the unexpected regime change in Malaysia in 2018 coupled with Dr. Mahathir Mohamad becoming the prime minister (2018-2020) for a second time saw the resurgence of the LEP.

\section{FOREIGN POLICY SHIFTS AND CONTINUITY UNDER A NEW REGIME}

Regime change is usually associated with democratic or non-democratic shifts in government. In the Malaysian case however, the novelty related to an unexpected but peaceful transition of the dominance of one party (from power after over six decades of rule), by a new coalition of veteran and new politicians. In 2018, an opposition alliance, the Pakatan Harapan (PH) won the elections. It was an unexpected victory that ended the ruling Barisan Nasional (BN) coalition's 60-year grip on political power in the country. PH comprising Parti Pribumi Bersatu Malaysia, Parti Keadilan Rakyat, Democratic Action Party and Parti Amanah Negara, won 113 seats, followed by BN with 79 seats. The winning coalition was led by Dr. Mahathir Mohamad. Interestingly, the change in government was a replacement of the entire ruling group by some of the same as well as opposition lawmakers from the established political parties.

The change in government had a direct effect on Malaysia's foreign policy orientation. Continuity and shifts in foreign policy under $\mathrm{PH}$ was directly related to internal dynamics as well as the changes in the international environment. Mainly, two factors determined Malaysian foreign policy recalibration - the need to accommodate IR 4.0 and dealing with the rise of China. Understanding that Malaysia needed to strengthen trade and investment ties to the Japanese market in order to cope with IR 4.0, yet again Japan became the focal point in PH's foreign policy through the reinvigoration of LEP 2.0. ${ }^{16}$ Equally, the revival of the LEP was a means to diversify Malaysia's economic and foreign policy partners in the context of overwhelming Chinese investments that had entered the Malaysian market during former Prime Minister Najib Tun Razak's administration. This had to be done as previously the LEP became sidelined during Najib

\footnotetext{
${ }^{13}$ Japanese firms diversifying their investments in Malaysia.

${ }^{14}$ Ministry of International Trade and Industry of Malaysia, Industry 4WRD: National Policy on Industry 4.0, Government of Malaysia Publication, 2018, p.36.

${ }^{15}$ Tang Siew Mun, Reviewing Mahathir's and Malaysia's Foreign Policy, Fulcrum, 22 June 2018, retrieved from https://fulcrum.sg/reviewing-mahathirs-and-malaysias-foreign-policy-by-tang-siew-mun/ accessed on 12 October 2020.

${ }^{16}$ Mazwin Nik Anis, Exciting times ahead with second wave of LEP, The Star, 14 December 2013, retrieved from https://www.thestar.com.my/news/nation/2013/12/14/exciting-times-ahead-with-second-wave-of-lep-najib-workingtogether-will-bring-about-collective-su, accessed on 12 October 2020.
} 
Razak's administration even though there were attempts to revive it in 2013. The half-hearted attempt to revive the LEP 2.0 failed due to the fact Kuala Lumpur was more interested in courting Beijing. ${ }^{17}$

As we all know PH was commandeered by a rather towering personality, Dr. Mahathir Mohamad whose belief system was defined by so called Asian values and the fact that he had high regards for Japan. As such his foreign policy showed elements of continuity rather than those of discontinuity. What was apparent was the degree of concentration shifted more towards Japan without sidelining China. Mahathir's desire to have more collaboration between Malaysia and Japan, led to the establishment of the second iteration of the LEP, commonly known as LEP 2.0.

During Mahathir's first ever visit to Japan in June 2018, which was after being sworn in as prime minister he pledged to revitalize LEP by focusing on elevating trade and investment potential in priority areas that would expedite Malaysia's adoption into the IR 4.0 under the country's National Policy on Industry 4.0. According to Malaysia's Ambassador-Designate to Japan, Datuk Kennedy Jawan, LEP 2.0 is an initiative to advance investments as well as trade knowledge with Japan to accelerate Malaysia's adoption into the IR 4.0. ${ }^{18}$ The main idea was for Malaysian companies to collaborate with Japan to create a conducive investment environment that would encourage more innovations in automation and information technology. To this end, Malaysia expected to cooperate with existing Japanese companies in Malaysia, like that of Sony, Panasonic, Konica Minolta, Daihatsu, Sharp, Hitachi and Sumitomo. These companies had already adopted IR 4.0 principles and the expectation was these companies will extend the application to their manufacturing bases and supply chains in Malaysia. In so doing, more small and medium Malaysia companies were expected to benefit from the collaboration. The LEP provided much opportunities for Japanese investments into Malaysia. For example, the Malaysian Investment Development Authority (MIDA) reported that Japanese foreign direct investments between January and September 2019 increased four times to 11.81 billion ringgit (USD2.83 billion). ${ }^{19}$ MIDA also pointed out that Chinese investments into Malaysia halved in the same period. Conversely, as early as June 2019, during the prime minister's working visit to Japan, Malaysian Digital Economy Corporation (MDEC), MIDA and JETRO made an effort to bring together Japanese companies from various sectors which were interested in investing and develop new technologies in Malaysia, especially robotics, e-commerce, blockchain and artificial intelligence. ${ }^{20}$ However, because of the collapse of the $\mathrm{PH}$ government in the following year, it is difficult to

\footnotetext{
${ }^{17}$ Tang Siew Mun, Reviewing Mahathir's and Malaysia's Foreign Policy, Fulcrum, 22 June 2018, retrieved from https://fulcrum.sg/reviewing-mahathirs-and-malaysias-foreign-policy-by-tang-siew-mun/ accessed on 12 October 2020.

${ }^{18}$ Malaysia-Japan ties to soar to new heights with Look East Policy 2.0, Borneo Post, 18 January 2019, retrieved from https://www.theborneopost.com/2019/01/18/malaysia-japan-ties-to-soar-to-new-heights-with-look-east-policy2-0/, accessed on 18 August 2020.

${ }^{19}$ Chinese investments in Malaysia halve, U.S inflow soars, Yahoo News, 29 November 2019, retrieved from https://sg.news.yahoo.com/chinese-investments-malaysia-halve-u100720224.html?guccounter=1\&guce_referrer=aHR0cHM6Ly93d3cuZ29vZ2xlLmNvbS8\&guce_referrer_sig=AQ AAALv2nIXKWnM2Qrr-

ISHHHMMRVh1HMPNe8jT13WPXZITbC1NNgdRzOTrvCSRxV_ILlcH1WrkTKJG217qd4MjTmpgflixvqAMTZ m6WyFT-lpJ-qwKd-u8r2TDsbJVhLBkaHpRDZQNwftX-iRD0VF-Y0Ruy8Nh8zULfIGM9_QRVKSG4, accessed on 18 January 2020.

${ }^{20}$ Malaysian Digital Economy Corporation, MDEC attracts support from Japanese companies to Malaysia, Press Release, 12 June 2019, retrieved from https://mdec.my/wp-content/uploads/FOR-IMMEDIATE-RELEASEMDEC-Attracts-Support-From-Japanese-Digital-Industry_v3.pdf, accessed on 18 January 2020.
} 
ascertain if Malaysian companies did indeed benefit in trying to adapt to the IR 4.0 platform due to increased Japanese investments.

Within the context of the LEP 2.0, Malaysian companies would then be able to tap into areas like aerospace, halal foods and services, technology related to renewable energy, healthcare, multimedia and content products and services which the Japanese have already invested in. Promoting halal products became one of the main pillars in the LEP 2.0. The Malaysia External Trade Development Corporation and the Ministry of International Trade and Industry (MITI) encouraged Malaysian companies to promote and supply their halal products and services in Japan especially during the soon to be held 2020 Tokyo Olympics. ${ }^{21}$ Chief Executive Officer of MATRADE, Dato' Wan Latiff Wan Muss observed that,

Japan has indicated its interest to source for Halal products and services in an effort to accommodate the visit of Muslim tourists and athletes at Tokyo Olympic. There is a potential of more than 140 million meals to be required at the Olympics Athlete Village and approximately 720 million Halal meals to be prepared during the event. Given Malaysia's close relationship with Japan and the strong credibility of Malaysian Halal products and services due to JAKIM's Halal certification, we are confident Malaysia has a stronger position to be the main provider for Halal during Tokyo Olympic 2020. ${ }^{22}$

By August 2019, local companies were already scheduled to supply products for the Tokyo Olympics such as Golden Fresh Sdn Bhd (supplying frozen seafood products), Bangi Golf Resort (supplying ready-to-eat packaged halal food) and Hernan Corporation (exporting mochi durian products). ${ }^{23}$ Going beyond the Olympics, MATRADE wanted more collaborations with Japanese companies on halal foods so that Malaysian products can be a commonly found in Japanese chain stores, supermarkets, and fast-food restaurants.Through the Malaysia-Japan Economic Partnership Agreement, Malaysian companies were expected take advantage of the prevailing tariff removal and reduction on export of products into Japan.

Besides trade and investment links, Dr. Mahathir Mohamad also reached out to Prime Minister Shinzo Abe for loans to help reduce Malaysia's national debt which was linked to megaprojects given to Chinese-linked companies during the previous government. ${ }^{24}$ By November 2018, Japan agreed to issue yen-denominated bonds of up to 200 billion yen ( $\$ 1.8$ billion) to assist

\footnotetext{
${ }^{21}$ Malaysia External Trade Development Corporation, Digital Trade Halal Value Chain for Tokyo Olympic 2020 Initiative Launched, 15 August 2019, retrieved fromhttps://www.matrade.gov.my/en/announcements/177-pressreleases/press-releases-2019/4679-digital-trade-halal-value-chain-for-tokyo-olympic-2020-initiative-launched, accessed on 18 November 2020.

${ }^{22}$ Malaysia External Trade Development Corporation, Digital Trade Halal Value Chain for Tokyo Olympic 2020 Initiative Launched, 15 August 2019.

${ }^{23}$ Malaysia External Trade Development Corporation, Digital Trade Halal Value Chain for Tokyo Olympic 2020 Initiative Launched, 15 August 2019.

${ }^{24}$ Tang Siew Mun, Reviewing Mahathir's and Malaysia's Foreign Policy, Fulcrum, 22 June 2018, retrieved from https://fulcrum.sg/reviewing-mahathirs-and-malaysias-foreign-policy-by-tang-siew-mun/ accessed on 12 October 2020.
} 
Malaysia deal with government debt. ${ }^{25}$ In an effort to raise funds amid huge debts, Malaysia issued a 200 billion yen (USD1.80 billion) samurai bond in March 2019. The issuance was guaranteed by the Japan Bank for International Cooperation (JBIC). The samurai bond was sold to Japanese investors subject to Japanese regulations. The idea was for the government to use access to Japanese capital to "financing development expenditure such as the building of schools, hospitals, public roads and other utilities." 26

Apart from yen loans, education became another important feature in strengthening bilateral relations. Dr. Mahathir Mohamad found the Japanese successful because their education system was practical in nature where knowledge was combined with teaching of appropriate values. ${ }^{27}$ With support from him, many Japanese educational institutions became interested in opening up branch campuses in Malaysia. For instance, University of Tsukuba showed keen interest in a establishing a branch campus in the country. The original plan was to set up a branch campus of Tsukuba University within University Malaya in Kuala Lumpur sometime in 2020. However, the launch was postponed to 2023 due to the emergence of COVID 19 pandemic. When established, it would be the very first overseas branch campus by a Japanese university. ${ }^{28}$ The idea of setting up a branch is linked to education and business whereby graduates from the university would be able to work in Japanese multinational companies located all over Malaysia. Prior to this, under the first phase of the LEP, Malaysian students were sent to Japanese institutions to obtain training and degrees in a variety of fields. According to Dr. Mahathir Mohamad, "having the branch campuses of Japanese universities in Malaysia can save the country a third of the cost of sending students to Japan... more students can benefit if the Japanese universities are set up in Malaysia." ${ }^{29}$ It is expected that Tsukuba University together with another Japanese influenced institution - the Malaysia-Japan International Institute of Technology (MJIIT) which was established in 2011, will not only reflect the strengthened cooperation between Japan and Malaysia in years to come but also produce graduates with values that the Japanese are known for.

\section{MALAYSIA- CHINA RELATIONS}

The rekindling of Malaysia-Japan relations and the LEP 2.0, needs to be understood within the broader context of Malaysia's ties with China. The re-introduction of the LEP was also a signal PH government's interest to work closer with Japan compared to the previous government under Najib Abdul Razak which was courted closely by Beijing. Malaysia's move to expand cooperation with Japan can be explained by a desire to reduce overreliance on Chinese investments. However, Dr. Mahathir Mohamad was equally careful not to sideline China.

\footnotetext{
${ }^{25}$ Mari Yamaguchi, Japan to provide loan to help Malaysia battle debt problem, AP News, 6 November 2018, retrieved from https://apnews.com/article/39d85f918e4a4517baec3a4a30ff7e58, accessed on 13 November 2020.

${ }^{26}$ Khairani Afifi Noordin, In the Know How: The Samurai Bonds, The Edge Markets, 20 August 2019, retrieved from https://www.theedgemarkets.com/article/intheknow-samurai-bonds, / accessed on 12 October 2020.

${ }^{27}$ Having Japanese universities in Malaysia can save cost: Mahathir, The Sun daily, 8 August 2019, retrieved from https://www.thesundaily.my/local/having-japanese-universities-in-malaysia-can-save-cost-mahathir-NF1236719, accessed on 29 October 2020.

${ }^{28}$ Tsukuba comes to Malaysia, The Star, 25 October 2020, retrieved from

https://www.thestar.com.my/news/education/2020/10/25/tsukuba-comes-to-malaysia, accessed on 29 October 2020.

${ }^{29}$ Having Japanese universities in Malaysia can save cost: Mahathir, The Sun daily, 8 August 2019, retrieved from https://www.thesundaily.my/local/having-japanese-universities-in-malaysia-can-save-cost-mahathir-NF1236719, accessed on 29 October 2020.
} 
In previous administrations, Malaysia-China relations were already robust with China being the biggest trading partner in the country. But the $\mathrm{PH}$ government was critical of the terms involved in Chinese domestic investments in Malaysia. PH policymakers found irregular financial arrangements between Malaysian and Chinese firms under the premiership of Najib Razak who embraced the 2013 China's Belt and Road Initiative (BRI) by investing in a slew of projects. ${ }^{30}$ The Cases of alleged dubious business ventures between Chinese companies and 1 Malaysia Development Berhad (1 MDB), the troubled state-owned investment fund linked to Prime Minister Najib was also a cause of concern to many. ${ }^{31}$ Before Malaysia's general elections in May 2018, Mahathir persistently criticized the Najib government about Chinese foreign direct investments, indicating he was not keen on BRI projects coming into Malaysia without proper appraisal. Understanding that these projects cannot be easily dismantled, the PH government began investigating and renegotiating the cost of each project. After renegotiating and once Mahathir had tailored BRI projects according to the priorities of his government he supported the BRI fully. After re-negotiations that lasted almost a year, several BRI projects were reinstated like the Bandar Malaysia, Malaysia - China Kuantan Industrial Park (MCKIP), as well as the Malacca Gateway. Another example was the East Coast Rail Link (ECRL) which was revived by April 2019, with the cost reduced by a whopping RM21.5billion. ${ }^{32}$

In the external environment, Malaysia continued to support China, especially the Chinese tech giant Huawei which Americans presumed was involved in cyber espionage. Dr. Mahathir Mohamad criticized the Americans for confronting China in the trade and security sectors. ${ }^{33}$ Recognizing the deployment of 5G will boost ICT and digital technology in digital economy, Dr. Mahathir supported Huawei's agreement with one of Malaysia's biggest telecommunication firms - Maxis - to obtain access to 5G cellular technology. ${ }^{34}$ According to Daniel Moss from Bloomberg the decision to support Huawei does not signal that Malaysia prefers China but rather that Dr. Mahathir Mohamad supports Asian vendors compared to their Western competitors. ${ }^{35}$ However, seem from a different angle, Dr. Mahathir Mohamad has always sought to have affable relations with China. When asked by a journalist if Malaysia was taking a softer approach towards China, the prime minister replied, "we want to be friendly with all the countries in the world; we do not want to be at war with people. We know their strengths and we know our weaknesses." As such,

\footnotetext{
${ }^{30}$ Mark Rao, Reviving the ECRL could dent confidence in govt's political will, The Malaysian Reserve, 23 January 2019, retrieved from https://themalaysianreserve.com/2019/01/23/reviving-the-ecrl-could-dent-confidence-in-govtspolitical-will/accessed on 12 September 2020.

${ }^{31}$ Mark Rao, Reviving the ECRL could dent confidence in govt's political will, The Malaysian Reserve, 23 January 2019, retrieved from https://themalaysianreserve.com/2019/01/23/reviving-the-ecrl-could-dent-confidence-in-govtspolitical-will/accessed on 12 September 2020.

32 Yiswaree Palansamy, ECRL: So, what's the deal with Pakatan's new deal?, Malay Mail, 16 April 2019, retrieved from https://www.malaymail.com/news/malaysia/2019/04/16/ecrl-so-whats-the-deal-with-pakatans-newdeal/1743409, accessed on 12 October 2019.

${ }_{33}$ Kelly Olsen, Malaysia's Mahathir: We try to use Huawei technology 'as much as possible' CNBC News, 30 May 2019, retrieved from https://www.cnbc.com/2019/05/30/mahathir-we-try-to-use-huawei-technology-as-much-aspossible.html, accessed on 13 August 2020.

${ }^{34}$ Maxis seals 5G deal with Huawei, readies for 2020 roll-out, The Edge Markets, 4 October, 2019, retrieved from https://www.theedgemarkets.com/article/maxis-seals-5g-deal-huawei-readies-2020-rollout, accessed on 5 September 2020.

${ }^{35}$ Daniel Moss, Mahathir Uses Huawei to Needle the U.S., Bloomberg Opinion, 20 June 2019, retrieved from https://www.bloomberg.com/opinion/articles/2019-06-19/mahathir-uses-huawei-to-needle-u-s-tout-support-for-asia, accessed on 12 June 2020.
} 
while Japan was an important trading and investment partner to Malaysia, Dr. Mahathir was careful not to sideline a rising China for the sake of national interests. ${ }^{36}$

In addition to the decision on Huawei, the PH government also opted to retain the Chinese ecommerce giant, Alibaba-led Digital Free Trade Zone (DFTZ), an official Belt and Road, in Malaysia. The DFTZ was negotiated by the Najib administration to support Malaysian small and medium enterprises. The expectation was that the digital platform would advance Malaysian exports and attract regional e-commerce into the country. According to MATRADE, among others, the DFTZ aims to global customers to be in contact with Malaysian manufacturers / sellers, turn Malaysia into a regional ecommerce hub for brands to reach ASEAN customers and to develop a Malaysian an ecosystem that is comfortable with internet economy and e-commerce. ${ }^{37}$ It is predicted that by 2025 Malaysia's e-commerce platform will be worth USD8 billion. More importantly Malaysia's Alibaba led DFTZ is supported by the Malaysia Digital Economic Corporation (MDEC) and the Electronic World Trade Platform (EWTP) in booting e commerce ties globally. ${ }^{38}$ By April 2018, over 100 small and medium enterprises joined Alibaba's Lazada ecommerce platform to sell their products. Later many more small and medium enterprises joined the DFTZ. Malaysia's e-commerce industry benefitted when Chinese private companies invested USD295 million worth of FDI into Malaysia in 2018. ${ }^{39}$ What this indicates is that the PH government did not limit Chinese investors nor enterprises from entering Malaysia despite the resumption of the LEP. In other words, Malaysian foreign policy displayed continuity in embracing China during the PH government. While pursuing positive relations with China, Dr. Mahathir Mohamad still attempted to "steer Malaysia from its over-dependency on China." 40

\section{PAKATAN HARAPAN AND SHIFTING / CONTINUING FOREIGN POLICIES}

The question is what is the link between regime change and foreign policy? As previously mentioned before, with PH's win in 2018, the LEP gained renewed momentum and greater visibility in Malaysian foreign policy without sidelining China. To understand how this policy unfolded, we need to know what infused changes as well as continuity in Malaysian foreign policy. In other words, as Charles Hermann questioned, what are the sources of foreign policy

\footnotetext{
${ }^{36}$ Huawei produces better phones than America: Tun M, 31 May 2019, The Sun Daily, retrieved from https://www.thesundaily.my/local/huawei-produces-better-phones-than-america-tun-m-MI930439, accessed on 31 May 2020.

${ }^{37}$ MATRADE, Digital Free Trade Zone, retrieved from https://www.matrade.gov.my/en/digital-free-trade-zonedftz, accessed on 10 June 2020.

${ }^{38}$ Hugh Harsono, The China-Malaysia Digital Free Trade Zone: National Security Considerations, The Diplomat, 25 July 2020, retrieved from https://thediplomat.com/2020/07/the-china-malaysia-digital-free-trade-zone-nationalsecurity-considerations/, accessed on 20 August 2020.

${ }^{39}$ Hugh Harsono, The China-Malaysia Digital Free Trade Zone: National Security Considerations, The Diplomat, 25 July 2020, retrieved from https://thediplomat.com/2020/07/the-china-malaysia-digital-free-trade-zone-nationalsecurity-considerations/, accessed on 20 August 2020.

${ }^{40}$ Tang Siew Mun, Reviewing Mahathir's and Malaysia's Foreign Policy, Fulcrum, 22 June 2018, retrieved from https://fulcrum.sg/reviewing-mahathirs-and-malaysias-foreign-policy-by-tang-siew-mun/, accessed on 12 October 2020.
} 
recalibration. ${ }^{41}$ According to him four sources can be identified. They are leader driven, bureaucratic advocacy, domestic restructuring, and external shock.

In terms of leader driven, Hermann describes how a leader who is authoritative has the power to re-direct policy preferences. ${ }^{42}$ Dr. Mahathir's strong personality and 21 years of being the prime minister of Malaysia from 1981 to 2003, he was forceful as well as regarded as the elderly statesman of the country. His dominance in foreign policymaking saw continuity as well as changes in foreign policy in accordance to his perception of Malaysia's national interests. Known for his anti-western stance, the LEP was launched to emulate Japanese development and economic success. When LEP was first introduced, Japan, South Korea and Taiwan were the main economic models that Malaysia looked into. But during Dr. Mahathir's second term, it was clear that the PH government saw a rising China as part of the LEP based on nonpartisanship rather than exploitative premise. In conclusion, for Dr. Mahathir, both Japan and China were important but over dependency on China was to be avoided at all costs.

For a policy like the LEP to be effective, Hermann points out the need for bureaucratic advocacy which means agencies or groups within the government who are responsive towards such a re-direction in policy. ${ }^{43}$ In September 2019, the PH government articulate its key foreign policy priorities through the launch of the Foreign Policy Framework (FPF) for a New Malaysia: Change in Continuity. ${ }^{44}$ The FPF outlined the direction of foreign policy of the New Malaysia, empowered the Ministry of Foreign Affairs, enhance inter-agency cooperation and increased public and civil society participation in foreign policy decision-making processes. As Elina Noor points out the "change in continuity" idea basically advocates some minor policy corrections and adjustments. ${ }^{45}$ More importantly, the new framework urged for a better inter- agency coordination. This meant that Malaysia -Japan relations were supported by various government agencies and coalition parties. Agencies like MATRADE and MIDA were catalyst in advancing several initiatives to promote trade and investments with Japan. For example not only does MATRADE promote Malaysian exports to Japan, together with MIDA and Halal Development Corporation (HDC), the agency championed halal cooperation between the two countries. ${ }^{46}$ With such commitment from inter agencies, the LEP advanced quite well in the 22 months PH governed.

In terms of domestic restructuring, Hermann indicates regimes need "politically relevant segment of society whose support a regime needs to govern." ${ }^{47}$ In terms of Malaysia, the people who supported the PH coalition to win against a ruling party that had governed the country for over 6 decades can be construed as a politically motivated society. The main aim of the PH supporters was to oust the Najib administration which was mired in corruption scandal due to the

\footnotetext{
${ }^{41}$ Charles F. Hermann, Changing Course: When Governments Choose to Redirect Foreign Policy, International Studies Quarterly, Vol. 34, 1990, p. 11.

${ }^{42}$ Charles F. Hermann, Changing Course: When Governments Choose to Redirect Foreign Policy, International Studies Quarterly, Vol. 34, 1990, p. 11.

${ }^{43}$ Charles F. Hermann, Changing Course: When Governments Choose to Redirect Foreign Policy, International Studies Quarterly, Vol. 34, 1990, p. 11.

${ }^{44}$ MyGovernment, Foreign Policy Framework of The New Malaysia, retrieved form https://www.malaysia.gov.my/portal/content/30903, accessed on 12 October 2020.

${ }^{45}$ Elina Noor, Foreign and Security Policy in The New Malaysia, Lowy Institute, 7 November 2019.

${ }^{46}$ Malaysia External Trade Development Corporation, MATRADE Champions The Promotion of Halal in Japan, 1 November 2019, retrieved from https://www.matrade.gov.my/en/about-matrade/017.media/press-releases/4748matrade-champions-the-promotion-of-halal-in-japan, accessed on 1 December 2020.

${ }^{47}$ Charles F. Hermann, Changing Course: When Governments Choose to Redirect Foreign Policy, International Studies Quarterly, Vol. 34, 1990, p. 12.
} 
I MDB case. Since the LEP was not a new policy nor was Japan a controversial trading and investment partner, Dr. Mahathir had no problem to rekindle the almost defunct LEP. But the many were vary of Chinese investments in Malayisa. During the Najib administration, the opposition government accused the Najib administration of "opening the floodgates for the foreign power to influence local parties". Parti Pribumi Bersatu Malaysia president Tan Sri Muhyiddin Yassin claimed that locals were uneasy with the increase in mainland Chinese investments into Malaysia. ${ }^{48}$ According to Wan Saiful Wan Jan, the Chief Executive of the Institute for Democracy and Economic Affairs (IDEAS) many Malaysians were distrustful about Chinese investments and feared that these investments will be used as a contrivance to expand communism. Additionally, he pointed out that lack of transparency in issuing contracts to Chinese investors is another cause for concern. ${ }^{49}$ Against this background, Japan and the LEP was more easily accepted by the populace compared to China related investments or influence.

Lastly, Hermann's understanding of external shock refers to "dramatic international events" that could affect policies. ${ }^{50}$ Notably, he outlines the importance of visibility and direct impact on the country. ${ }^{51}$ What was visible to the PH government was the fact that US-China trade war and Chinese - Japanese competition for investments in Southeast Asia. As a relatively small country, Dr. Mahathir Mohamad did not want to be embroiled in major power confrontations. Malaysia has always maintained a neutral foreign policy and most importantly has maintained equidistance between major players. The LEP became a vehicle that helped Malaysia to partner with Japan while moving away from depending too heavily on mainland Chinese investments.

\section{CONCLUSION}

When PH began to govern, the country was reportedly in debt. According to the Ministry of Finance,

...a substantial portion of the government's debt and liabilities, which stood at RM1.087 trillion as at end-2017, comprises hidden debt and liabilities that the previous government "had deceitfully kept under wraps or disguised as off-balance sheet items". 52

There were a lot of expectations from the populace that the PH government would do better than the previous government mired in corruption scandals. Hence Malaysia's foreign policy was

\footnotetext{
${ }^{48}$ Should Malaysians be concerned over growing China investments?, Bernama News, 19 January 2017, retrieved from https://www.astroawani.com/berita-bisnes/should-malaysians-be-concerned-over-growing-china-investments129494 , accessed on 1 December 2020.

${ }^{49}$ Wan Saiful Wan Jan, Malaysia's Priority is to Manage, not Stop, China's Investments, Perspective, issue 46, 2017, retrieved from https://www.iseas.edu.sg/images/pdf/ISEAS_Perspective_2017 46.pdf, accessed on 12 December 2020.

${ }^{50}$ Charles F. Hermann, Changing Course: When Governments Choose to Redirect Foreign Policy, International Studies Quarterly, Vol. 34, 1990, p. 12.

${ }^{51}$ Charles F. Hermann, Changing Course: When Governments Choose to Redirect Foreign Policy, International Studies Quarterly, Vol. 34, 1990, p. 12.

${ }^{52} \mathrm{MoF}$ defends rise of direct debt under PH government, The Edge Markets, 29 September 2019, retrieved from https://www.theedgemarkets.com/article/mof-defends-rise-direct-debt-under-ph-government, accessed on 29 September 2020.
} 
premised upon not tilting towards Japan, rather, the resumption of LEP 2.0 was a function of regime legitimation through which $\mathrm{PH}$ wanted to diversify its foreign policy partners for the goal of expanding investment and collaboration opportunities. Japan became significantly important in helping the government manage the national debt. Japanese investments not only assisted in managing the debt but also in financing future infrastructure projects. Simultaneously, recognizing that Malaysia is far behind in adapting to IR 4.0, the LEP was one avenue where Japanese investments could be used to accelerate small and medium companies' adaption into digital technologies and economy.

Where China was concerned, the PH government understood that Chinese investments should not be dismissed. Eventually, it can be argued that Malaysia's look east orientation expanded to include China. This was inevitable, of course, given China's remarkable rise and its increasing economic and geopolitical importance in the region. Initially, PH had problems with how the BRI project contracts were awarded by the previous government and not with China itself. At the same time, Malaysia was faced with a dependent dilemma where it did not want to be too reliant on one source of investments which was China. It could be considered therefore that Malaysian foreign policy orientation could be defined as combination of domestic economic needs and political legitimation. Despite PH's ascendancy, research suggests that Malaysia's foreign policy towards Japan indicated a surprising degree of continuity albeit with some minor policy adjustments. All in all, Malaysia capitalized on a rising China while sidestepping against too much of reliance on China by moving closer to Japan. Consequently, there was a shift as well as continuity in Malaysia foreign policy under the $\mathrm{PH}$ government.

\section{REFERENCES}

Amyx, J. and Drysdale, P., (Eds.), Japanese governance: Beyond Japan Inc., London, Routledge Curzon, 2003.

Chinese investments in Malaysia halve, U.S inflow soars, Yahoo News, 29 November 2019, retrieved from https://sg.news.yahoo.com/chinese-investments-malaysia-halve-u100720224.html?guccounter=1\&guce_referrer=aHR0cHM6Ly93d3cuZ29vZ2xlLmNvbS8\&guc e_referrer_sig=AQAAALv2nIXKWnM2QrrISHHHMMRVh1HMPNe8jT13WPXZITbC1NNgd RzOTrvCSRxV_ILlcH1WrkTKJG217qd4MjTmpgflixvqAMTZm6WyFT-lpJ-qwKdu8r2TDsbJVhLBkaHpRDZQNwftX-iRD0VF-Y0Ruy8Nh8zULfIGM9_QRVKSG4, accessed on 18 January 2020.

Elina Noor, Foreign and Security Policy in The New Malaysia, Lowy Institute, 7 November 2019, retrieved from https://www.lowyinstitute.org/publications/foreign-and-security-policynew-malaysia, accessed on 8 November 2020. 
Embassy of Japan in Malaysia, Overview of Japan-Malaysia Relationship, retrieved from https://www.my.emb-japan.go.jp/English/bilateral/Overview_bilateral.htm, accessed on 9 October 2020.

Harsono, Hugh, The China-Malaysia Digital Free Trade Zone: National Security Considerations, The Diplomat, 25 July 2020, retrieved from https://thediplomat.com/2020/07/the-china-malaysiadigital-free-trade-zone-national-security-considerations/, accessed on 20 August 2020.

Having Japanese universities in Malaysia can save cost: Mahathir, The Sun Daily, 8 August 2019, retrieved from https://www.thesundaily.my/local/having-japanese-universities-inmalaysia-can-save-cost-mahathir-NF1236719, accessed on 29 October 2020.

Hermann, Charles F, Changing Course: When Governments Choose to Redirect Foreign Policy, International Studies Quarterly, Vol. 34, 1990, pp. 3-21.

Huawei produces better phones than America: Tun M, 31 May 2019, The Sun Daily, retrieved from https://www.thesundaily.my/local/huawei-produces-better-phones-than-america-tun-mMI930439, accessed on 31 May 2020.

Japanese firms diversifying their investments in Malaysia, Bernama, 4 October 2020, retrieved from https://www.freemalaysiatoday.com/category/nation/2020/10/04/japanese-firmsdiversifying-their-investments-in-malaysia/, accessed on 12 October 2020.

Katayama, Kazuyaki, China's Rise and Japan's Malaysia Policy, UM Press, 2013.

Khairani Afifi Noordin, In the Know How: The Samurai Bonds, The Edge Markets, 20 August 2019, retrieved from https://www.theedgemarkets.com/article/intheknow-samurai-bonds, / accessed on 12 October 2020.

Khadijah Md Khalid, "Malaysia-Japan relations: Explaining the root causes of the pro-Japan orientation of Malaysia in the post1981 period," unpublished $\mathrm{PhD}$ thesis, London School of Oriental and African Studies - SOAS, University of London, 1999.

Lai Yew Meng, Looking East Again? Malaysia-Japan Relations in the 21St Century, Manu, Vol.26, 2017, pp. 1-27.

Malaysian Digital Economy Corporation, MDEC attracts support from Japanese companies to Malaysia, Press Release, 12 June 2019, retrieved from https://mdec.my/wpcontent/uploads/FOR-IMMEDIATE-RELEASE-MDEC-Attracts-Support-From-JapaneseDigital-Industry_v3.pdf, accessed on 18 January 2020.

Malaysia External Trade Development Corporation, Bilateral Free Trade Agreements, retrieved on https://www.matrade.gov.my/en/etrade/24-malaysian-exporters/going-global/68-bilateral-fta, accessed on 12 November 2020. 
International Journal of East Asian Studies

Vol. 9, No. 1, 2020. pp. 75-88.

doi.org/10.22452/IJEAS.vol9no1.6

Malaysia External Trade Development Corporation, Digital Free Trade Zone, retrieved from https://www.matrade.gov.my/en/digital-free-trade-zone-dftz, accessed on 10 June 2020.

Malaysia External Trade Development Corporation, Digital Trade Halal Value Chain for Tokyo Olympic 2020 Initiative Launched, 15 August 2019, retrieved fromhttps://www.matrade.gov.my/en/announcements/177-press-releases/press-releases2019/4679-digital-trade-halal-value-chain-for-tokyo-olympic-2020-initiative-launched, accessed on 18 November 2020.

Malaysia External Trade Development Corporation, MATRADE Champions The Promotion of Halal in Japan, 1 November 2019, retrieved from https:/www.matrade.gov.my/en/aboutmatrade/media/press-releases/4748-matrade-champions-the-promotion-of-halal-in-japan, accessed on 1 December 2020.

Malaysia-Japan ties to soar to new heights with Look East Policy 2.0, Borneo Post, 18 January 2019, retrieved from https://www.theborneopost.com/2019/01/18/malaysia-japan-ties-to-soar-tonew-heights-with-look-east-policy-2-0/, accessed on 18 August 2020.

Maxis seals 5G deal with Huawei, readies for 2020 roll-out, The Edge Markets, 4 October, 2019, retrieved from https://www.theedgemarkets.com/article/maxis-seals-5g-deal-huawei-readies2020-rollout, accessed on 5 September 2020.

Mazwin Nik Anis, Exciting times ahead with second wave of LEP, The Star, 14 December 2013, retrieved from https://www.thestar.com.my/news/nation/2013/12/14/exciting-times-ahead-withsecond-wave-of-lep-najib-working-together-will-bring-about-collective-su, accessed on 12 October 2020.

Ministry of International Trade and Industry of Malaysia, Industry 4WRD: National Policy on Industry 4.0, Government of Malaysia Publication, 2018.

MoF defends rise of direct debt under PH government, The Edge Markets, 29 September 2019, retrieved from https://www.theedgemarkets.com/article/mof-defends-rise-direct-debt-under-phgovernment, accessed on 29 September 2020.

Moss, Daniel, Mahathir Uses Huawei to Needle the U.S., Bloomberg Opinion, 20 June 2019, retrieved from https:/www.bloomberg.com/opinion/articles/2019-06-19/mahathir-uses-huaweito-needle-u-s-tout-support-for-asia, accessed on 12 June 2020.

MyGovernment, Foreign Policy Framework of The New Malaysia, retrieved form https://www.malaysia.gov.my/portal/content/30903, accessed on 12 October 2020.

Olsen, Kelly, Malaysia's Mahathir: We try to use Huawei technology 'as much as possible' CNBC News, 30 May 2019, retrieved from https://www.cnbc.com/2019/05/30/mahathir-we-tryto-use-huawei-technology-as-much-as-possible.html, accessed on 13 August 2020. 
Palansamy, Yiswaree, ECRL: So, what's the deal with Pakatan's new deal?, Malay Mail, 16 April 2019, retrieved from https://www.malaymail.com/news/malaysia/2019/04/16/ecrl-sowhats-the-deal-with-pakatans-new-deal/1743409, accessed on 12 October 2019.

Rahman, K.M., Molla, R.I. \& Murad, M.W., Japan-Malaysia Free Trade Agreement: Expectations and achievements, Electronic Journal of Contemporary Japanese Studies, 2008, pp.29-42.

Rao, Mark, Reviving the ECRL could dent confidence in government's political will, The Malaysian Reserve, 23 January 2019, retrieved from https://themalaysianreserve.com/2019/01/23/reviving-the-ecrl-could-dent-confidence-in-govtspolitical-will/accessed on 12 September 2020.

Should Malaysians be concerned over growing China investments?, Bernama News, 19 January 2017, retrieved from https://www.astroawani.com/berita-bisnes/should-malaysians-beconcerned-over-growing-china-investments-129494, accessed on 1 December 2020.

Tang Siew Mun, Reviewing Mahathir's and Malaysia's Foreign Policy, Fulcrum, 22 June 2018, retrieved from https://fulcrum.sg/reviewing-mahathirs-and-malaysias-foreign-policy-by-tangsiew-mun/ accessed on 12 October 2020.

Tsukuba comes to Malaysia, The Star, 25 October 2020, retrieved from https://www.thestar.com.my/news/education/2020/10/25/tsukuba-comes-to-malaysia, accessed on 29 October 2020.

Wan Saiful Wan Jan, Malaysia's Priority is to Manage, not Stop, China's Investments, Perspective, issue 46, 2017, retrieved from https://www.iseas.edu.sg/images/pdf/ISEAS_Perspective_2017_46.pdf, accessed on 12 December 2020.

Yamaguchi, Mari, Japan to provide loan to help Malaysia battle debt problem, AP News, 6 November 2018, retrieved from https://apnews.com/article/39d85f918e4a4517baec3a4a30ff7e58, accessed on 13 November 2020 . 
International Journal of East Asian Studies

Vol. 9, No. 1, 2020. pp. 75-88.

doi.org/10.22452/IJEAS.vol9no1.6 